\title{
Марина Столяр
}

\section{МЕТАФІЗИКА СМІХУ У ФІЛОСОФСЬКОМУ ДИСКУРСІ ХІХ СТОЛІТТЯ.}

\section{Moland, L. (Ed.). (2018). All Too Human. Laughter, Humor, and Com- edy in Nineteenth-Century Philosophy. Boston: Springer.}

Останніми роками вже склалася традиція на початку книги чи статті, присвяченої проблемам сміху, трохи поскаржитися на недооцінку їх важливості філософською спільнотою. У цьому відношенні не є винятком і збірка статей «Занадто людське. Сміх, гумор і комедія у філософії XIX століття». Та наразі скарги $\epsilon$ виправданими, оскільки, по-перше, автори наважуються не лише акцентувати увагу на метафізичному тлумаченні феномену сміху, але і здійснити відповідну інтерпретацію на матеріалі... філософї XIX cm. Коли йдеться про філософію сміху, - зазначає редактор збірки Лідія Моланд - праці філософів XIX ст. здебільшого згадуються мимохіть, якщо взагалі беруться до уваги [Moland 2018: 3]. Вона намагається пояснити це сприйняттям німецьких мислителів як найсерйозніших із усіх філософів, що, на додаток, виглядають на своїх портретах досить «набундюченими» (приблизний переклад слова «јowly»). Контраст між темою сміху, з одного боку, і вченнями й образами вищезгаданих особистостей, з іншого, занадто яскравий, щоб не наражатися на жарти колег [ibid.: 1-2].

Пропонована праця є сукупністю статей, автори яких намагаються виправити наслідки недооцінення внеску мислителів XIX ст. у філософію сміху. Авторів об’єднує єдина мета: показати дуже важливе зрушення, що відбулося у філософії XIX ст. Поворот до теми сміху, який стався ще у XVIII ст., у XIX поглибився метафізичним, релігійно-екзістенційним осмисленням сміху та похідних від сміху понять комічного, гумору, жарту тощо. Також у книзі стверджується, що саме починаючи з XIX ст. гумор став ще однією призмою, дивлячись крізь яку ми міркуємо про те, що значить «бути людиною» («ще однією»- моє уточнення, у тексті йдеться просто про призму).

Як на мене, остання теза навіть із таким уточненням є спірною, враховуючи, зокрема, зміст праці Лідії Амір [Amir 2014]. Проте Моланд високо оцінює внесок Амір у розвиток теорії сміху на грунті вивчення історії філософії XVIII-XIX ст. Нагадаю, що Амір у своїй книзі «Гумор і добре життя в модерній філософії...» дослідила роль гумору у формуванні високої якості людського життя на матеріалі філософських вчень переважно XVIII cm. [Amir 2014; Столяр 2018]. Та наразі

(C) М. Столяр, 2020 
абстрагуймося від можливих застережень, що можуть іти з цього боку, і зосередьмося на філософії сміху доби романтизму.

Збірка складається з одинадцяти розділів, в яких, згідно з хронологічним порядком, аналізуються теорії сміху XIX ст., як вони розгорталися в найрізноманітніших і здебільшого невідомих сучасному читачу напрямах. Книга розпочинається з філософії Георга Гегеля й завершується аналізом філософії сміху Анрі Бергсона, яка теж отримує нове звучання в контексті пізніх праць французького філософа.

Лідія Моланд, авторка перших двох розділів, відкриває книгу коротким екскурсом в історію вчень про сміх (Платон, Аристотель, Декарт, Гобс, Кант, Шилер, пост-кантіанські естетики), який вона завершує «революцією Стерна» (Laurence Sterne, 1713-1768), англійського письменника XVIII ст. У першому розділі (параграфи 1.4 та 1.5) Моланд пропонує стислий огляд провідних ідей наступних розділів збірки, що вельми полегшує для читача пошук необхідної інформації. Дуже зручною є також і вся структура збірки, де кожна частина розділена на невеличкі параграфи відповідно до аспектів, що аналізуються.

У другому розділі Моланд зупиняється на специфіці Гегелевого розуміння таких різновидів смішного, як комічне та гумор. Зокрема, ідеться про використання Гегелем поняття гумору у двох сенсах - суб'єктивному й об'єктивному. Зрозуміло, що відповідні поняття авторка розкриває в контексті загальної філософської системи Гегеля.

Моланд нагадує, що філософія Гегеля за суттю $є$ філософією синтезу протилежностей, примирення. Гегель утверджує цілісність істини. Та це ціле, щоб отримати всю свою повноту, має також включати в себе розділення, яке не може бути стійким. Воно має знову дійти до згоди із цілим. Звідси випливає висока оцінка Гегелем комедій Аристофана, які зображували соціальну єдність, зруйновану суб'єктивністю, а потім - відновлення єдності [Moland 2018: 16-17]. Biдомо, що особливо високо філософ цінував «Хмари» Аристофана. На матеріалі цієї комедії авторка показує, як Гегель підкреслив деякі важливі положення своєї філософії. По-перше, «Хмари» блискуче демонструють єдність і суперечність. Головний герой комедії, Стрепсіад, руйнує етичне ціле, відвідуючи академію Сократа в надії, що той навчить його, як позбутися кредиторів. І в якийсь момент Стрепсіадові це вдається. Та коли його софістичні засоби бере на озброєння син, відкидаючи повагу до батька, тоді розлючений Стрепсіад підпалює академію. Як вважає Гегель, герой при цьому заперечує перше заперечення й відновлює етичне ціле, яке, враховуючи руйнацію, залучає в себе також і розділення, що відбулося. По-друге, п’єса передає філософське переконання Гегеля в тому, що людина є джерелом божественного, а відтак - джерелом нормативності. I по-третє, комедія торкається найістотніших тем: як люди мають ставитися до божественного, в який спосіб вони повинні керувати собою й що означає «бути вільним» [ibid.: 18].

Саме до таких комедій, як Аристофанові «Хмари», Гегель і застосовує поняття об'єктивного гумору. Цей гумор, на думку Гегеля, формує блискучі взірці мистецтва, оскільки сам є втіленням Ідеї. При цьому філософ не стає на бік голої схеми й не заперечує важливість побутових деталей та авторського суб'єктивізму. Просто він вважає, що через усі подробиці людського життя має проступати прихована глибина. Саме тому Гегель захоплюється Стерном, сприймаючи його 
як митця, здатного використовувати дрібниці, щоб запропонувати найвищу ідею глибини, демонструючи в повсякденній роз'єднаності речей їхній глибинний внутрішній зв'язок [ibid.: 21-22].

Значно менше подобаються Гегелю наступники старої комедії (Менандр, Плавт і Теренцій), бо вони концентрують увагу на домашніх конфліктах і побутових сценах, за якими не стоїть нічого глибшого. Гегель уважає, що ці комедії зазнають невдачі, оскільки не здатні зобразити єдність і боротьбу. Вони анітрохи не розвивають людські уявлення про божественне й нехтують найважливішими темами. Також Гегель негативно оцінює сатиру, бо вона прагне розділення й зупиняється на ньому, чіпляється за дисгармонію й не бажає єдності [ibid..: 18].

У межах суб'єктивного гумору художник використовує суб'єктивні поняття, індивідуальні способи інтерпретації, щоб знищити об'єктивне як таке, розчинити все об'єктивне у своїй суб' єктивності. Таке перебільшення ролі суб'єктивності, на думку Гегеля, виводить артефакт мистецтва за межі останнього взагалі, оскільки автор не докладає зусиль до примирення людини й Бога. Ексцентричні персонажі можуть змусити нас сміятися, але їхні низькі цілі не змінюються, відповідні заперечення моралі не завершуються примиренням. Ці артефакти демонструють винятково суб'єктивний гумор. Якщо мистецтво доходить стадії суб'єктивного гумору, - уважає Гегель, - то йому вже нема куди йти далі, воно вже не може розвиватися [ibid.: 20-22].

Звичайно, Гегель не заперечує суб'єктивності художника в межах об'єктивного гумору, але він вважає, що, коли художник привносить в об'єкт своє суб'єктивне бачення, трансформуючи цей об'єкт, внутрішній рух об'єктивної реальності має все одно залишатися пріоритетним у творі мистецтва. Об'єктивний гумор додає глибоке почуття, вдалу дотепність, геніальні роздуми, інтелектуальний рух, які оживлюють і поглиблюють найменші деталі. Художник трансформує об'єкт і водночас сам змінюється цим об’єктом. Така творчість підносить об'єкти й постає як перетин об'єктивного змісту й суб'єктивного інтересу. Потреба в мистецтві $\epsilon$ не що інше, як розумне прагнення людини підняти внутрішній і зовнішній світ на рівень духовного усвідомлення. Суб'єктивна художня творчість, у межах якої людина не здатна піднестися до розуміння себе як співтворця, не дає чуттєвого розуміння істини й тому не може вважатися мистецтвом, - підсумовує Моланд думку Гегеля [ibid..].

Розвинувши тези цього розділу, можна дійти таких висновків: 1) комедія і трагедія як артефакти справжнього мистецтва по суті для Гегеля не відрізняються; 2) не тільки трагедія і комедія відповідають Ідеї, але й сама Ідея має... трагікомічний вимір; 3) відповідно, естетика $є$ метафізикою на певному етапі розгортання Ідеї, а 4) теорія сміху є, певною мірою, метафізичною теорією.

Авторка зазначає, що приклади об'єктивного гумору Гегеля є зовсім не смішними, але якщо ми застосуємо його методологію до аналізу сучасної комедії (чи кінокомедіï), то побачимо, що ця оптика прекрасно «працює» [ibid.: 28-30]. Хоча, звичайно, зрозуміти успіх (чи провал) тієї чи іншої комедії неможливо лише на основі гегелівської методології, проте хочеться привернути особливу увагу дослідників до актуальності відповідних ідей Гегеля для сучасних культурології, естетики та мистецтвознавства.

Третій розділ збірки («Це трагічно, але велично: К. В. Ф. Зольгер і гумор як ключ до метафізики», автор Паоло Дієго Буббіо) присвячено поняттям гумору й 
іронії в тлумаченні філософа й естетика Карла Зольґера (1780-1819), учня Шелінга.

У Зольгера гумор і іронія також постають як метафізичні категорії, що виражають наше розуміння парадоксального зв'язку між нескінченним і скінченним. Естетичний досвід для Зольгера є одним (і можливо, найкращим) із засобів осягнення людиною глибокої метафізичної істини: те, що ми сприймаємо як нескінченну сутність або ідею, з необхідністю має бути розчиненим у скінченному бутті. Людина не може сприймати нескінченне в інакший спосіб. Краса передбачає видимість, а видимість - тимчасовість. Саме тому краса підкоряється неминучості долі [Bubbio 2018: 36].

Якщо ми розуміємо красу як святкування трагедії скінченності й тимчасовості, то таке бачення буття, за Зольгером, є іронічним. Іронія уможливлюється через бачення суперечності між скінченним і нескінченним, розуміння нездійсненності примирення між ними. Іронія, як їі розуміє Зольгер, є виявом трагічного зіткнення тимчасового й нескінченного [ibid.: 41, 43].

Відношення скінченного й нескінченного Зольгер описує через поняття подвійного заперечення. Тлінне, скінченне заперечує себе, щоб звільнити місце для вічного, нескінченного, а нескінченне заперечує себе, щоб утілитися в скінченному. Відтак іронія й гумор (якщо останній розуміти в широкому сенсі слова як смішне й дотепне) постають двома боками однієї медалі: іронія - це одкровення крізь призму ідеї, а гумор - одкровення з боку чуттєвості [ibid.: 36].

Щоб виразити сутність концепції Зольгера, Буббіо наводить такий анекдот:

«Колись жив чоловік, який розмовляв із Богом. "Боже, - запитав чоловік, - наскільки довгим є мільйон років?” Бог відповів: “У моїй системі відліку, синку, це, як одна хвилина”. Тоді чоловік поцікавився: “Боже, а наскільки цінним є мільйон доларів?” Бог відповів: “Для мене, це як один цент”. I чоловік попросив: “Боже, можна мені дати цей один цент?” “Хвилиночку” - відповів Бог» [ibid.: 33].

Як на мене, цей анекдот досить яскраво демонструє зіткнення скінченного і нескінченного, тобто виражає ідею Зольгера про іронію як один зі способів осягнення істини. При цьому іронічне виявляється не тільки естетичною, але й метафізичною категорією [ibid.: 36].

У третьому параграфі Буббіо зосереджує увагу на пов'язаних між собою поняттях смішного, дотепного й гумору, інтерпретуючи їх у контексті загальної теорії іронії Зольгера [ibid.: 39-42]. Автор статті висуває гіпотезу, згідно з якою саме Зольер передбачив концепцію гумору, що може слугувати засобом аналізу сучасного мистецтва. Зокрема він використовує естетику Зольгера для інтерпретації творчості Семюела Бекета, Вінсента Ван Гога й Рене Магріта [ibid.: 41-44].

Наступна четверта частина збірки вже в назві містить інтригу: «Безумство Жан Поля або гумор як транс-критика». Автор цієї частини - Вільям Коукер має на меті проаналізувати гумор і гумористичний стиль Жан Поля на рівнях риторики, сюжетів його творів і теорії самосвідомості. На кожному із цих рівнів Жан Поль, з точки зору Коукера, створює напругу між протилежностями в пошуках ефекту, який він визначає як інверсію піднесеного [Coker 2018: 52]. Теорія 
гумору Жан Поля, з точки зору автора статті, є витонченою альтернативою романтичній програмі Фридриха Шльогеля, Новаліса й Тіка та відповіддю на проблеми, сформульовані Жан-Жаком Русо й Імануелем Кантом [ibid.].

Провідний німецький теоретик гумору й один із найпопулярніших романістів Жан Поль (псевдонім Йогана Пауля Фридрих Ріхтера, 1763-1825) розробив поетику протилежностей на противагу діалектиці гармонії, яку пропонували його сучасники. Жан Поль наполягав на посиленні антитез і поглибленні суперечностей, а не на примиренні протилежностей. Його естетика має некласичний нахил, оскільки він здійснює розрив із гармонією, мірою, піднесеним [ibid.: 53], що певною мірою наближає цю естетику до художніх практик авангардизму й модернізму.

На відміну від інших теоретиків гумору (можливо, за винятком лише Сьорена К`єркегора - M. C.), Жан Поль наважився навіть самого себе представляти як комічну постать, про що згадує в одному листі до Гете Фридрих Шилер. Із цього листа випливає, що Жан Поль виглядав просто безглуздо, якщо не безумно. Його свідомо ігрові практики суперечили «благородній простоті» й «мовчазній величі» представників Ваймарського істеблішменту [ibid.: 51-52]. Це було щось на кшталт практик юродивих - таку можливість не слід виключати, маючи на увазі метафізично-релігійні конотації теорії сміху Жан Поля, який підносить дотепність на прикладі... «дива народження нашого Творця», - події, в якій відбувся перетин нескінченного і скінченого [ibid.: 52].

Коукер намагається довести: те, що змушувало титанів Ваймара дивитися на Жан Поля як на того, що з’їхав з глузду, було не просто мистецьким перфомансом. Ішлося про нероздільність життя і творчості Жан Поля в площині філософськи витлумаченого гумору.

Поняття гумору прийшло в німецьку культуру XVIII ст. із англійського роману, особливо зі творчості Лоренса Стерна, але дуже швидко проникло у філософський дискурс. I Жан Поль, випереджаючи думку Гегеля, уважав гумор особливою рисою саме сучасноӥ культури, на відміну від стародавньої, яка знала лише комічне [ibid.: 55].

Жан Поль розкриває свою теорію гумору у творі з дещо хуліганською назвою «Дитячий садок естетики» («Vorschule der Asthetik»). Але, попри грайливу манеру викладу, Жан Поль розглядає гумор у термінах філософських роздумів, властивих представникам німецької класичної філософії [ibid.: 53]. Онтологічною основою гумору Жан Поль, як і багато інших мислителів цього часу, вважає колізію нескінченного і скінченого. Саме через цю опозицію Жан Поль тлумачить кантівське протиставлення «царства свободи» й «царства необхідності» [ibid.: 55]. Місцем у теорії Жан Поля, де свобода й необхідність перетинаються, $€$ дотепність [ibid.: 54]. Гумор він розуміє як інверсію піднесеного [ibid.: 64]. Буббіо вважає, що таке розуміння включає його в традицію, яка йде від Канта до сучасних філософів зразка Кодзіна Каратані чи Славоя Жижека [ibid.: 65].

За Жан Полем, гумор і інтелект є щільно пов'язаними характеристиками. Гумор визріває разом із розумом, коли суб'єкт усвідомлює провалля між скінченним і нескінченним [ibid.: 54]. Тож відсутність почуття гумору вказує на проблеми інтелектуального характеру.

Коукер прослідковує витоки стилю Жан Поля в контексті не лише ідей Канта й Русо, але політичних реалій, зумовлених французькою революцією. Саме тому 
Жан Полеве розуміння гумору не є суто філософським, у ньому містяться й політичні підтексти [ibid.: 67]. Коукер зазначає, що відповідні конотації не завжди можна довести, бо тільки сучасники Жан Поля могли адекватно читати його тексти «між рядків». Проте Жан Поль був одним із небагатьох мислителів того часу, кого події Французької революції не спонукали зректися юнацького революційного ентузіазму [ibid.: 67-68]. Мені здається, що ця стійка пасіонарність може бути чинником, що почасти зумовив його теорію непримиренних протилежностей. Та залишається незрозумілим, яким чином він міг бачити протилежності непримиренними в масштабі нескінченного. Мабуть, пасіонарність наразі була сильнішою за раціональне мислення. I цей факт перекидає місток до теми сміху на грунті розуміння ірраціональності буття і мислення.

У контексті книги, присвяченої темі гумору у філософії XIX ст., досить важко було би проігнорувати важливість мистецтва карикатури, яке не просто існувало, але й процвітало в цей період. Саме тому Ален Спейт пропонує звернутися до творчості філософа-ідеаліста Карла Розенкранца (1805-1879), який розглядав різноманітні форми гумору, завершуючи свою працю «Естетика потворного» («Die Asthetik des Hasslichen») дослідженням феномену карикатури. На думку автора, украй важко переоцінити роль Розенкранца в розвитку естетики, яка в XIX ст. виходить за межі проблем прекрасного й піднесеного [Speight 2018: 73].

Почавши з викладу Розенкранцевої естетики потворного, Ален Спейт переходить до співвідношення між феноменом карикатури й філософією. Розенкранц уважав: якщо остання має представити себе в площині карикатури, то йдеться не про філософію взагалі, а про постаті конкретних філософів. Зокрема, Розенкранц зосереджував свою увагу на аристофанівській карикатурі Сократа [ibid.: 81-82]. Стосовно ж філософії взагалі, то вона, на думку Розенкранца, у принципі не може бути карикатурною чи карикатурно зображеною [ibid.: 81]. Та якщо ми згадаємо праці К'єркегора (я вже не кажу про праці сучасних філософів), то остання теза виглядатиме для нас досить сумнівною. Як на мене, К'єркегор, критикуючи данських гегельянців, на перших сторінках «Страху і трепету» дає блискучу карикатуру на базові, визначальні претензії філософії, починаючи від античності. Звичайно, подібну іронію не кожен помітить, а якщо й помітить, то не обов'язково відреагує посмішкою.

Карикатура в Розенкранца постає синтетичною формою, яка вивільняє протилежності, надаючи можливість побачити рух до поєднання приємного з піднесеним, а нікчемності потворного - із абсолютною красою [Speight 2018: 78]. Спосіб, у який ми сприймаємо карикатуру, вважав Розенкранц, дає можливість оцінити нашу здібність розуміти комічне. Правильне сприйняття виявляється в тому, що ви можете сміятися з людей, яких любите, і при цьому ваша любов до них не меншатиме (або, додам від себе, дивитися на людей, яких ви не любите, і завдяки карикатурі вже не ненавидіти їх, а хоч трохи їм симпатизувати). Урешті-решт, за Розенкранцем, карикатура має на меті показати людей такими, якими вони є насправді [ibid.: 85-86]. Зрозуміло, що наразі не йдеться про гостро сатиричну карикатуру. І це, як мені здається, правильно, якщо ми залишаємося в межах сміху як радості. Треба зазначити, що у філософії ХIX ст. до Ніцше релігійні й моральні міркування грали дуже важливу роль у теоретичних узагальненнях щодо сміхових практик. Мені здається, що саме це значною мірою зага- 
льмувало розвиток теорії зверхності: здатність філософа до рефлексії витіснялася його моральними настановами, і тому він не міг визнати, що подекуди його сміх має в собі певну долю глузливості.

Додам, що дослідників, які працюють із темою інваріантів у культурі, можуть зацікавити виявлені Розенкранцем карикатурні узагальнення - стереотипи, якими послуговується мистецтво карикатури [ibid.: 80-81].

Частина шоста збірки - «Артур Шопенгавер: гумор і жалюгідне становище людини». Новизна цієї розвідки полягає в тому, що, по-перше, автор працює 3 маловідомими широкому колу філософів першоджерелами - ранніми рукописами Шопенгавера [Wicks 2018: 89]. По-друге, традиційно сміх розглядається як окремий предмет інтересу Шопенгавера. Роберт Вікс намагається розширити дослідження. Він долучає до аналізу філософії сміху такі явища, як серйозність, музика і плач [ibid.: 92].

Автор демонструє, що в Шопенгавера поняття сміху і плачу, сміху й серйозності $є$ взаємопов'язаними. Він звертає увагу на діалектику сміху і плачу, їхню подібність як предметів теоретичного узагальнення [ibid.: 94-95]. Мені здається, що наразі визначається досить перспективний напрямок як розвитку теорії сміху, так і теорії плачу, оскільки до аналізу феномену плачу можна застосовувати дещо видозмінені теорії інконгруентності (The Incongruity Theory), приниження (The Inferiority Theory) та полегшення (The Relief Theory).

Шопенгавер формулює концепцію невідповідності в її класичному варіанті. Ми свідомо ведемо відлік цієї теорії сміху з Шопенгавера, а не з Канта, бо вважаємо, що погляди останнього не можуть бути однозначно інтерпретовані як одна $з$ теорій сміху, а саме теорія невідповідності [див.: Stoliar 2019: 129-130]. Вікс також звертає увагу на те, що деякі вислови Шопенгавера можна розуміти як аргументи на користь теорії полегшення або теорії зверхності (The Superiority Theory). Проте він наполягає, що Шопенгавер пов'язує сміх передовсім із когнітивним дисонансом. Тобто сміх виникає внаслідок сприйняття інконгруентності між очікуваннями й реальністю, сподіваннями й конкретною ситуацією. Відповідно, серйозність передбачає відсутність когнітивного дисонансу внаслідок сприйняття світу таким, яким він $\epsilon$ [ibid.: 93].

Якщо певна інконгруентність, усе ж, відкриється серйозній людині, то не буде для неї ані цікавою, ані смішною, а лише такою, що розчаровує. Є ще один різновид серйозності, коли людина сприймає світ як сповнений болючих невідповідностей. I, знову ж, світ в очах серйозної людини відповідає іiі концепції світу. Що ж до серйозності музики, то це зовсім інший рівень ставлення до дійсності. Музика, за Шопенгавером, принципово серйозна, бо вона є безпосередньою копією ядра реальності або «речі в собі» - Волі як сліпого імпульсу [ibid.: 95-96] (зазначу, що теза про неможливість комічного в музиці спростована музичними практиками XX-XXI ст.).

Автор статті демонструє, що Шопенгавер визнавав взаємозв'язок між музикою (серйозністю самої реальності), плачем (співчуттям до людства в його жалюгідному стані) і сміхом (гумористичною гіпотезою, що життя - це величезний фарс). Шопенгавер поєднує концепції плачу й музики з універсальною концепцією сміху, щоби прийти до характеристики стану людини, який містить дві протилежні перспективи: трагічне бачення буття як цілого й комічний погляд, що зупиняється на окремих деталях [ibid.: 98]. 
Якщо для Шопенгавера стан людства є жалюгідним, бо всіх людей захоплено у вир грандіозного фарсу буття, то Ніцше пропонує альтернативну позицію, роз'ясненням якої закінчується стаття Вікса. Для Ніцше сміх у жодному разі не має розглядатися як пов'язаний зі співчуттям до людей. Це має бути зверхній, переможний сміх, який виражає перемогу в жорстокій боротьбі за подолання співчуття до людини як жалюгідної істоти [ibid.: 100-101]. У такий спосіб, через відмову від традиційних цінностей, філософія Ніцше знову повертається обличчям до методологічних можливостей теорії зверхності, яку філософи XVIII і XIX ст. незрідка просто виключали з поля можливостей власної рефлексії й категорично заперечували через суто моральні, а не раціональні причини.

Наступну частину збірки, «Гумор як спасіння в песимістичній філософії Юліуса Банзена», Фредерік Бейзер присвятив розглядові місця гумору у філософській системі майже повністю забутого сьогодні Юліуса Фридриха Августа Банзена (1830-1881).

Автор нагадує, що філософський рух песимізму виникає в Німеччині другої половини XIX ст. I якщо всі знають батька цього руху, Шопенгавера, то Бейзер додає цілу низку дуже важливих для історії песимізму імен (Едуард фон Гартман, Філіп Майнлендер, Юліус Банзен, молодий Фридрих Ніцше), серед яких є й зовсім забуті, зокрема - Агнес Тауберт і Ольга Плюмахер. Як зазначає автор, це були дуже-дуже похмурі філософи, які занадто серйозно ставилися до свого песимізму. Та серед них був один, який високо цінував почуття гумору. А між тим він був найрадикальнішим із песимістів свого часу. Ідеться про практично невідомого сьогодні Юліуса Банзена [Beiser 2018: 107-108].

В оптиці свого похмурого бачення світу Банзен заперечував Шопенгавера й раннього Ніцше з їхніми програмами полегшення людських страждань засобами культури, мистецтва й релігії. Проте він покладав деякі надії (зрозуміло, що не дуже великі) на гумор. Це й був його «бренд» як філософа-песиміста. Поєднуючи волюнтаризм Шопенгавера й діалектику Гегеля, Банзен бачив життя сповненим суперечностей, які не знаходять свого розв'язання (він вважав волю не тільки сліпою, але й суперечливою) [ibid.: 110]. Сдино можливий перепочинок в суцільних стражданнях, на думку Банзена, дає гумор. Сміх піднімає людину над стражданнями, якщо вона здатна чесно подивитися на цей світ як жахливий [ibid.: 114].

Додамо, що ця стаття становить значний інтерес з точки зору своєрідного вступу до більш докладного дослідження історії песимістичної філософії, починаючи з XIX ст.

Два наступні розділи (восьмий і дев'ятий) присвячені філософії сміху Сьорена К'єркегора. Така увага до теорії сміху данського філософа не є випадковою, оскільки К'єркегорів стиль філософування був вельми дотепним. Джон Ліпіт автор розділу 9 - цілком справедливо вважає К'єркегора одним із найдотепніших письменників у західній філософській традиції. I Ліпіта дещо дивує, коли його студенти не можуть цього збагнути після цілого семестру вивчення творів данського філософа [Lippitt 2018: 137]. Оскільки К'єркегор розвиває думку про глибинний зв'язок християнської чесноти упокорення з жартом (жарт розглядається К'єркегором як певний різновид упокорення) [ibid.: 140], то це, справді, дещо важко усвідомити сучасній молодій людині, яка виховується в принципово іншій культурній парадигмі. Зв'язок жарту і упокорення у філософії К'єркегора 
свідчить про те, що не тільки філософська творчість, але й власне життя філософа було сповненим сміхових рефлексій на межі юродства.

Псевдоніми, під якими писав К'єркегор, на думку Марсії Робінсон (авторки восьмого розділу), не завжди виражають його позицію, але вони є необхідними суб'єктами в поліфонічному висвітленні проблеми сміху [Robinson 2018: 115], яка розглядається в контексті данського неогегельянського дискурсу того часу (особливо у зв'язку з філософією Йогана Людвига Хайберга й Ганса Ласена Мартенсена) [ibid.: 121]. Ліпіт додає, що саме під псевдонімом Йоганеса Клімакуса надруковано найважливіші думки філософа стосовно гумору [Lippitt 2018: 138].

Робінсон вважає, що сократівська іронія була для К’ еркегора певним взірцем духовної місії філософа в суспільстві. Авторка стверджує, що К'єркегор узяв на себе роль сократівського гедзя щодо данського християнського світу. При цьому К’єркегор не просто наслідував Сократа, яким той постає в платонівських діалогах, але використовував деяку форму філософської іронії, адаптовану до особливостей культури данської неогегельянської аудиторії [Robinson 2018: 121]. За допомогою дотепності, іронії, жартів, пародій та анекдотичних історій К'єркегор намагається привести найвидатніших представників данської інтелігенції до усвідомлення чогось дуже важливого й особистісного, про що вони або забули, або не бажали думати. Він хоче навернути формальних прибічників християнської релігії до справжнього християнства [ibid.]. Досягнення цієї мети передбачає, що не іронія, а гумор має стати визначною ознакою релігійної творчості філософа, бо саме гумор є гранично найближчою точкою (у процесі розгортання трьох стадій) відносно християнської релігії [ibid.]. Наразі позиції К’єркегора й Гегеля зближуються, оскільки Гегель вважає гумор найвищою формою романтичного мистецтва саме через здатність підважити все мистецтво [ibid.]. А Ліпіт уточнює: іронія й гумор розглядаються К'єркегором як підвиди комічного. У «Постскриптумі» іронія розкривається як гранична зона між естетичною й етичною сферами існування, а гумор - між етичною й релігійною [Lippitt 2018: 138].

За Робінсон, К'єркегор фактично став найяскравішою ілюстрацією концепту романтичного гумору Гегеля, згідно з якою цей різновид гумору завершує розвиток мистецтва й підводить до наступного, релігійного, щабля розгортання Духа. У свою чергу, К'єркегор запозичує в Гегеля ідею завершення людського мистецтва й початку божественного. Він уважає, що романтична іронія має сенс тільки в тому випадку, коли виражає серйозну екзістенційну позицію [Robinson 2018: 116]. Теми гумору й іронії хвилюють К'єркегора не просто як літературні прийоми, але як перспективи ставлення до життя або, за висловом авторки монографії «Жити поетично: К' єкегорова екзистенційна естетика» Сільвії Волш, «екзистенційні детермінанти» [Walsh 1994: 210].

Якщо Серен К'єркегор використовує іронію та гумор для оновлення християнства, то для Фридриха Ніцше, навпаки, сміх $є$ формою заперечення традиційних християнських цінностей. Метою десятого розділу «Божественний блазень: Ніцше про сміх і комедію», написаного Метью Маєром, є вивчення філософського значення сміху й комічного в Ніцше. Автор вважає, що, попри певну цікавість дослідників до цих тем, поза їі межами залишається найважливіше. Саме сміх Маєр вважає провідною темою всієї, а особливо пізньої (після «Заратустри») філософської творчості Ніцше [Meyer 2018: 154]. 
Маєр пише, що більша частина сучасних англо-американських досліджень із Ніцше зосереджена на виявленні етичних, епістемологічних і метафізичних поглядів німецького мислителя. При цьому поетичні аспекти його праць здебільшого залишаються поза увагою. Маєр нарікає, що навіть ті філософи, які досліджують окремі аспекти сміху у творчості Ніцше, усе ж, ігнорують потенціал інтерпретації всього філософського проекту Ніцше як центрованого довкола сміху й комедії [ibid.]. Автор не претендує на остаточне або вичерпне розуміння ролі, яку відіграє сміх або комедія у філософському проекті Ніцше. Проте прагне привернути увагу дослідників до сміху як дуже важливого, а з певного моменту навіть центрального, на його думку, аспекту філософії Ніцше [ibid.: 170].

У першому параграфі Маєр намагається навести докази цієї тези. Далі він поглиблює свої аргументи, порівнюючи пізню філософію Ніцше 3 діонісійськими комедіями Аристофана. Наприкінці праці робиться висновок про центральну роль сміху й комедії в ніцшеанському проекті самостворення та самовдосконалення людини, починаючи з «Веселої науки» (1882). Під «веселою наукою» Ніцше розуміє найкращий спосіб мислення, що демонструє єдність сміху й мyдрості. Ніцше сприймає сміх як спосіб утвердження життя в його повноті, включаючи потворні та дисгармонічні аспекти існування [ibid.: 156]. Зрештою, він використовує сміх як зброю проти християнської традиції [ibid.: 157].

Расел Форд, автор завершального розділу «Життєвий жарт: Бергсон, комедія і сенс сміху», пропонує дуже докладний аналіз праці Анрі Бергсона «Сміх». Теза Форда полягає в тому, що Бергсонові погляди на феномен сміху мають бути розглянуті в контексті всієї творчості французького філософа. Відповідну концепцію сміху можна зрозуміти повною мірою у зв'язку з пізнішими працями, де Бергсон розвиває ідею життєвого поривання (élan vital). На думку Форда, сміх для Бергсона $\epsilon$ не просто засобом виправлення негнучкості ізольованої людської істоти за умови відсутності співчуття до предмету сміху, але й сплеском природної, життєвої енергії, одним із найсуттєвіших її виявів у площині соціального буття [Ford 2018: 175-176]. Сміх виявляється вимогою самого життя, коли люди ставлять під сумнів сталі, зашкарублі суспільні форми й у такий спосіб виражають прагнення творити нові, життєздатніші й гнучкіші форми. Сміх є повстанням, що має людські масштаби, але більш глибоке, природне коріння [ibid.: 177]. Бо жартує саме́ життя (так приблизно я перекладаю семантику назви «Life's Joke...»). Іншими словами, комічне - це дія життя, яке виражає себе через сміх.

Тому Бергсон уникає дефініції комічного, яке для нього так само складне й невичерпне, як і життя. Натомість він пропонує образ міста з центральним проспектом, перехрестями вулиць і проїздами, що поділяють це місто на частини. Досліджуючи сміх, ми можемо ходити різними районами цієї предметної області, але завжди повертаємося до «центрального проспекту» [ibid.: 178].

На завершення Форд пише, що Бергсонова праця «Сміх», усвідомлював іiі автор метафізичний вимір проблеми комічного чи ні, є дуже важливою частиною метафізики філософа, розвинутої як у «Творчій еволюції», так і в більш пізнішому творі - «Два джерела моралі й релігії». В останньому Бергсон говорить про певну «динамічну релігію», перспективну для постійного поліпшення людства. Важливим засобом такої «релігії» Бергсон, безумовно, вважав сміх [ibid.: 192]. 
Читачеві, мабуть, уже впало у вічі, що назва збірки «Занадто людське...» містить алюзію на твір Ніцше «Людське, занадто людське: Книга для вільних духом» (нім. «Menschliches, Allzumenschliches: Ein Buch für freie Geister»). Я впевнена, що в редактора були певні підстави дати саме таку назву. Та мені здається, що це не зовсім відповідає сенсові книги в ціілому. По-перше, інтерпретація Ніцшевої концепції сміху в ній - лише один із сюжетів у межах цілої низки філософських концептів сміху ХІХ ст. Цей концепт не домінує, не узагальнює, а творчо завершує певний дискурс. По-друге ж, сміх як суто людське явище в цій книзі посутньо підноситься на рівень онтології. Це відбувається подібно до того, як веселі народні танці в XIX ст. стають модними в аристократичних колах, а народні пісні перетворюються на лейтмотиви симфоній. Саме тому я би назвала цю книгу: «Метафізика сміху у філософському дискурсі XIX ст...» Хоча, певна річ, 3 погляду видавця, зосередженого на комерційному успіхові, «All Toо Human...» звучить значно привабливіше.

Не можу погодитися із зауваженням укладачки щодо «безперечної хаотичності» збірки [Moland 2018: 2]. Мені здається, що завдяки цій праці образ філософії сміху XIX ст. як проблемної галузі метафізики постає у вигляді майже повного спектра відтінків, притаманних оптиці цієї доби, а не як начерк із великими білими плямами.

Думаю, що ця збірка буде корисною не тільки для істориків філософії й естетиків, але й для фахівців з філософської онтології, антропології, філософії культури. А насамперед вона має зацікавити молодих філософів як своєю оригінальністю, прозорим стилем викладу, так і перспективами новаторських досліджень, що їх накреслюють автори книги.

\section{СПИСОК ЛІТЕРАТУРИ}

Столяр, М. (2018). Філософія сміху та гумору в сучасному історико-філософскому дискуpci. Sententiae, 37(1), 168-178. https://doi.org/10.22240/sent37.01.168

Amir, A. (2014). Humor and the good life in modern philosophy: Shaftesbury, Hamann, Kierkegaard. Albany, NY: State University of New York Press.

Beiser, F. (2018). Humor as Redemption in the Pessimistic Philosophy of Julius Bahnsen. In L. Moland (Ed.), All Too Human. Laughter, Humor, and Comedy in Nineteenth-Century Philosophy (Vol. 7, pp. 105-114). Boston: Springer. https://doi.org/10.1007/978-3-319-91331-5_7

Bubbio, P. D. (2018). It's Tragic, But That's Great: K. W. F. Solger and Humor as the Key to Metaphysics. In L. Moland (Ed.), All Too Human. Laughter, Humor, and Comedy in Nineteenth-Century Philosophy (Vol. 7, pp. 33-49). Boston: Springer. https://doi.org/10.1007/978-3-319-91331-5_3

Coker, W. (2018). Jean Paul's Lunacy, or Humor as Trans-Critique. In L. Moland (Ed.), All Too Human. Laughter, Humor, and Comedy in Nineteenth-Century Philosophy (Vol. 7, pp. 51-71). Boston: Springer. https://doi.org/10.1007/978-3-319-91331-5_4

Ford, R. (2018). Life's Joke: Bergson, Comedy, and the Meaning of Laughter. In L. Moland (Ed.), All Too Human. Laughter, Humor, and Comedy in Nineteenth-Century Philosophy (Vol. 7, pp. 175-193). Boston: Springer. https://doi.org/10.1007/978-3-319-91331-5_11 
Lippitt, J. (2018). Jest as Humility: Kierkegaard and the Limits of Earnestness. In L. Moland (Ed.), All Too Human. Laughter, Humor, and Comedy in Nineteenth-Century Philosophy (Vol. 7, pp. 137-151). Boston: Springer. https://doi.org/10.1007/978-3-319-91331-5_9

Meyer, M. (2018). The Divine Hanswurst: Nietzsche on Laughter and Comedy. In L. Moland (Ed.), All Too Human. Laughter, Humor, and Comedy in Nineteenth-Century Philosophy (Vol. 7, pp. 153-173). Boston: Springer. https://doi.org/10.1007/978-3-319-91331-5_10

Moland, L. (2018a). Introduction: Taking Laughter Seriously in Nineteenth-Century Philosophy. In L. Moland (Ed.), All Too Human. Laughter, Humor, and Comedy in Nineteenth-Century Philosophy (Vol. 7, pp. 1-13). Boston: Springer. https://doi.org/10.1007/978-3-319-91331-5_1

Moland, L. (2018b). Reconciling Laughter: Hegel on Comedy and Humor. In L. Moland (Ed.), All Too Human. Laughter, Humor, and Comedy in Nineteenth-Century Philosophy (Vol. 7, pp. 15-31). Boston: Springer. https://doi.org/10.1007/978-3-319-91331-5_2

Robinson, M. (2018). 'What Time Is It? ... Eternity': Kierkegaard's Socratic Use of Hegel's Insights on Romantic Humor. In L. Moland (Ed.), All Too Human. Laughter, Humor, and Comedy in Nineteenth-Century Philosophy (Vol. 7, pp. 115-136). Boston: Springer. https://doi.org/10.1007/978-3-319-91331-5_8

Speight, C. A. (2018). Caricature, Philosophy and the "Aesthetics of the Ugly": Some Questions for Rosenkranz. In L. Moland (Ed.), All Too Human. Laughter, Humor, and Comedy in Nineteenth-Century Philosophy (Vol. 7, pp. 73-87). Boston: Springer. https://doi.org/10.1007/978-3-319-91331-5_5

Stoliar, M. (2018). The Philosophy of Laugh and Humor in the Modern Historical-philosophical Discourse. Sententiae, 37(1), 168-178. https://doi.org/10.22240/sent37.01.168

Stoliar, M. (2019). Immanuel Kant's Theory of Laughter and Philosophical Irony. In M. H. Bratasiuk, O. Ye. Gomilko, \& A. A. Kravchenko (Eds.), Philosophy and Values of the Modern Culture (pp. 122-141). Lviv, \& Toruń: Liha-Pres. https://doi.org/10.36059/978966-397-193-3/122-141

Walsh, S. (1994). Living poetically: Kierkegaard's existential aesthetics. University Park, PA: Pennsylvania State University Press, 1994.

Wicks, R. (2018). Arthur Schopenhauer: Humor and the Pitiable Human Condition. In L. Moland (Ed.), All Too Human. Laughter, Humor, and Comedy in Nineteenth-Century Philosophy (Vol. 7, pp. 89-104). Boston: Springer. https://doi.org/10.1007/978-3-319-91331-5_6

Одержано 23.01.2020

\section{REFERENCES}

Amir, A. (2014). Humor and the good life in modern philosophy: Shaftesbury, Hamann, Kierkegaard. Albany, NY: State University of New York Press.

Beiser, F. (2018). Humor as Redemption in the Pessimistic Philosophy of Julius Bahnsen. In L. Moland (Ed.), All Too Human. Laughter, Humor, and Comedy in Nineteenth-Century Philosophy (Vol. 7, pp. 105-114). Boston: Springer. https://doi.org/10.1007/978-3-319-91331-5_7

Bubbio, P. D. (2018). It's Tragic, But That's Great: K. W. F. Solger and Humor as the Key to Metaphysics. In L. Moland (Ed.), All Too Human. Laughter, Humor, and Comedy in Nineteenth-Century Philosophy (Vol. 7, pp. 33-49). Boston: Springer. https://doi.org/10.1007/978-3-319-91331-5_3 
Coker, W. (2018). Jean Paul's Lunacy, or Humor as Trans-Critique. In L. Moland (Ed.), All Too Human. Laughter, Humor, and Comedy in Nineteenth-Century Philosophy (Vol. 7, pp. 51-71). Boston: Springer. https://doi.org/10.1007/978-3-319-91331-5_4

Ford, R. (2018). Life's Joke: Bergson, Comedy, and the Meaning of Laughter. In L. Moland (Ed.), All Too Human. Laughter, Humor, and Comedy in Nineteenth-Century Philosophy (Vol. 7, pp. 175-193). Boston: Springer. https://doi.org/10.1007/978-3-319-91331-5_11 Lippitt, J. (2018). Jest as Humility: Kierkegaard and the Limits of Earnestness. In L. Moland (Ed.), All Too Human. Laughter, Humor, and Comedy in Nineteenth-Century Philosophy (Vol. 7, pp. 137-151). Boston: Springer. https://doi.org/10.1007/978-3-319-91331-5_9

Meyer, M. (2018). The Divine Hanswurst: Nietzsche on Laughter and Comedy. In L. Moland (Ed.), All Too Human. Laughter, Humor, and Comedy in Nineteenth-Century Philosophy (Vol. 7, pp. 153-173). Boston: Springer. https://doi.org/10.1007/978-3-319-91331-5_10 Moland, L. (2018a). Introduction: Taking Laughter Seriously in Nineteenth-Century Philosophy. In L. Moland (Ed.), All Too Human. Laughter, Humor, and Comedy in Nineteenth-Century Philosophy (Vol. 7, pp. 1-13). Boston: Springer. https://doi.org/10.1007/978-3-319-91331-5_1

Moland, L. (2018b). Reconciling Laughter: Hegel on Comedy and Humor. In L. Moland (Ed.), All Too Human. Laughter, Humor, and Comedy in Nineteenth-Century Philosophy (Vol. 7, pp. 15-31). Boston: Springer. https://doi.org/10.1007/978-3-319-91331-5 2

Robinson, M. (2018). 'What Time Is It? ... Eternity': Kierkegaard's Socratic Use of Hegel's Insights on Romantic Humor. In L. Moland (Ed.), All Too Human. Laughter, Humor, and Comedy in Nineteenth-Century Philosophy (Vol. 7, pp. 115-136). Boston: Springer. https://doi.org/10.1007/978-3-319-91331-5_8

Speight, C. A. (2018). Caricature, Philosophy and the "Aesthetics of the Ugly": Some Questions for Rosenkranz. In L. Moland (Ed.), All Too Human. Laughter, Humor, and Comedy in Nineteenth-Century Philosophy (Vol. 7, pp. 73-87). Boston: Springer. https://doi.org/10.1007/978-3-319-91331-5_5

Stoliar, M. (2018). The Philosophy of Laugh and Humor in the Modern Historical-philosophical Discourse. [In Ukrainian]. Sententiae, 37(1), 168-178. https://doi.org/10.22240/sent37.01.168

Stoliar, M. (2019). Immanuel Kant's Theory of Laughter and Philosophical Irony. In M. H. Bratasiuk, O. Ye. Gomilko, \& A. A. Kravchenko (Eds.), Philosophy and Values of the Modern Culture (pp. 122-141). Lviv, \& Toruń: Liha-Pres. https://doi.org/10.36059/978966-397-193-3/122-141

Walsh, S. (1994). Living poetically: Kierkegaard's existential aesthetics. University Park, PA: Pennsylvania State University Press, 1994.

Wicks, R. (2018). Arthur Schopenhauer: Humor and the Pitiable Human Condition. In L. Moland (Ed.), All Too Human. Laughter, Humor, and Comedy in Nineteenth-Century Philosophy (Vol. 7, pp. 89-104). Boston: Springer. https://doi.org/10.1007/978-3-319-91331-5_6

Received 23.01.2020 


\section{Maryna Stoliar}

Metaphysics of laughter in Nineteenth-century philosophical discourse. Moland, L. (Ed.). (2018). All Too Human. Laughter, Humor, and Comedy in Nineteenth-Century Philosophy. Boston: Springer.

Review of Moland, L. (Ed.). (2018). All Too Human. Laughter, Humor, and Comedy in Nineteenth-Century Philosophy. Boston: Springer.

\section{Марина Столяр}

Метафізика сміху у філософському дискурсі XIX століття. Moland, L. (Ed.). (2018). All Too Human. Laughter, Humor, and Comedy in NineteenthCentury Philosophy. Boston: Springer.

Огляд Moland, L. (Ed.). (2018). All Too Human. Laughter, Humor, and Comedy in Nineteenth-Century Philosophy. Boston: Springer.

Maryna Stoliar, D.Sc. (Philosophy), the Head of the Chair of Philosophy and Cultural Studies, associated professor of Department of Philology at T.H. Shevchenko National University «Chernihiv Colehium».

Марина Столяр, доктор філософських наук, професор, зав. кафедри філософї та культурології Національного університету «Чернігівський колегіум» імені Т.Г.Шевченка.

e-mail: stolyr.marina@gmail.com 